\title{
The South American Way: Sub-regional Integration under ALBA and UNASUR and International Dispute Resolution
}

\author{
MANuel A. GóMEZ* \\ Have you ever danced in the tropics? \\ With that hazy lazy \\ Like, kind of crazy \\ Like South American Way
}

(Carmen Miranda \& Bando Da Lua, 1959)

\begin{abstract}
This article describes two of the most recent sub-regional integration efforts in South America, namely ALBA and UNASUR, including the factors that have contributed to their development. The analysis offered here pays special attention to the role played by the Venezuelan government, particularly during the administration of former president Hugo Chavez, both in political and economic terms toward the rise and growth of ALBA. This article also explains how the heavy dependence on Venezuela's support was also detrimental to ALBA for it has been negatively affected by the crisis currently faced by the Latin American country. In contrast to the case of ALBA, this article discusses the rise of UNASUR as a collective endeavor and the efforts of its members to create a regional framework that includes a novel proposal of a Centre for the Settlement of Investment Disputes.
\end{abstract}

Keywords: Latin America, Sub-regional integration, UNASUR, International dispute resolution, ALBA

\section{INTRODUCTION}

This article describes two of the most recent sub-regional integration efforts in South America, namely ALBA and UNASUR, including the factors that have contributed to their development. The analysis offered here pays special attention to the role played by the Venezuelan government, particularly during the administration of former president Hugo Chavez, both in political and economic terms toward the rise and growth of ALBA. This article also explains how the heavy dependence on Venezuela's support was also detrimental to ALBA for it has been negatively affected by the crisis currently faced by the Latin American country. In contrast to the case of ALBA, this article discusses the rise of UNASUR as a collective endeavor and the efforts of its members to create a regional framework that includes a novel proposal of a Centre for the Settlement of Investment Disputes.

Section II of this article describes context and the conditions that led to the rise and growth of ALBA and UNASUR as part of the most recent wave toward regional integration

* Associate Professor of Law, Associate Dean of International \& Graduate Studies at Florida International University College of Law, magomez@fiu.edu. The author thanks Professor Csongor István Nagy, Ph.D., LL.M., S.J.D., dr. juris, for the kind invitation to publish this article, and to Professor Gilberto Guerrero Rocca for his valuable insights about international investment disputes in Latin America. This thematic issue (Missed and new opportunities in world trade. Eds. Csongor István Nagy \& Zoltán Víg) was published as part of the research project of the HAS-Szeged Federal Markets ‘Momentum' Research Group. 
in Latin America and the Caribbean. This section also discusses the critical role of Hugo Chavez in marshaling the promotion of regional integration in Latin America as a way to expand his political base and build strategic alliances throughout the region and beyond. This article also offers a comparison between ALBA and UNASUR regarding their scope, structure and other features, therefore highlighting some important differences and similarities among them.

Section III turns its attention to the proposal made within the framework of UNASUR to create a Centre for the Settlement of Investment Disputes as a better alternative to ICSID. This section delves into some of the main features of this proposed dispute processing mechanism and briefly mentions some of its challenges. Section IV contains a brief conclusion.

\section{LATIN AMERICAN INTEGRATION 2.0}

Regional and sub-regional integration have been an aspiration of Latin American countries for many decades. ${ }^{1}$ One would imagine that such goals are easy to attain given the geographical proximity, comparable challenges and common historical ties that bind the countries of the region. Nevertheless, the road to integration has been rocky to say the least. Latin American countries have attempted to organize and build strong alliances that help them tackle their common obstacles and strengthen their presence in the regional and global markets as the European Union emerged, grew stronger and became a powerful global competitor. $^{2}$

With a few exceptions, Latin American arrangements have tended to involve only a sub-group of countries and have also mainly focused on trade relations and economic integration e.g. MERCOSUR, CAN, CARICOM, CARIFTA, DR-CAFTA. Notwithstanding, some of the most recent efforts, in part due to the leadership of countries like Venezuela, have also focused on political integration. The two most notable examples of these latter efforts are the Bolivarian Alliance for the Peoples of Our Americas (ALBA, for its initials in Spanish: Alianza Bolivariana para los pueblos de nuestra América) ${ }^{3}$ and the Union of South American Nations (UNASUR, for its initials in Spanish: Unión de Naciones Suramericanas). ${ }^{4}$

Both ALBA and UNASUR stemmed or gained force from initiatives championed by Hugo Chavez, the self-proclaimed father of the Bolivarian Revolution and president of Venezuela between 1999 and 2013. Chavez named his political movement after Simon Bolivar, the $19^{\text {th }}$ century Venezuelan hero who led the independence of several South American nations from Spain and first proposed the idea of a united continent that would stand strong against the colonial European superpowers. ${ }^{5}$ The 170 years that passed between Bolivar's death in 1830 and the election of Chavez as president of Venezuela in 1999, witnessed many ups and downs throughout Latin America.

The former Spanish and Portuguese colonies (Brazil), upon gaining independence, were able to attain their own national identities and cultures, build their own legal systems, government institutions and other structures typical of any modern society. On the other

\footnotetext{
1 Baumann (2008) link 1.

2 Indart, Lengyel (1995) link 2.

3 See, Portalalba (2017) link 3.

4 See, UNASURSG (2017) link 4.

5 Gómez (2012).
} 
hand, they also endured intermittent periods of civil war, political instability, and economic crises. Contingent upon their relative wealth, which often derived from the exploitation of natural resources, their institutional and political stability, and other factors; some Latin American and Caribbean countries did better than their neighbors during certain periods of time, but the region as a whole always fell short of attaining an ideal level of progress and integration.

The rise of Chavez as a regional leader of sorts and the widespread of his political movement was not only a product of his charismatic personality or populist tactics, but also the result of Venezuela's sudden wealth caused by a meteoric increase in the price of oil that started in the year 2000. Such perfect combination allowed a relative outsider to politics like Chavez to purchase votes, harvest political allies and to also ruffle many anti-American, anti-capitalist feathers across the region and beyond. Chavez's political movement vowed to eradicate poverty and inequality, promote economic progress and development, and fight the expansion of capitalism by promoting a new version of socialism dubbed 'Twenty-first century socialism' (Socialismo del Siglo Veintiuno).

Some of the most visible allies were Fidel Castro from Cuba, Evo Morales from Bolivia, Lula Da Silva and Dilma Roussef from Brazil, Rafael Correa from Ecuador, Daniel Ortega from Nicaragua and Cristina Kirchner from Argentina. Other important leaders from Latin America and beyond were also openly sympathetic to the movement and to Chavez's unapologetic demeanor and provocative rhetoric especially against the United States, which contributed to cement his image as a world leader for the disenfranchised.

\section{The dawn and dusk of ALBA?}

ALBA (which also means 'dawn' in Spanish) emerged from a bilateral agreement signed between Cuba and Venezuela in 2000 whereby Cuba sent doctors, teachers and sport trainers to Venezuela in exchange for a quota of Venezuela's oil production. ${ }^{6}$ The agreement was marshaled as an effort to promote social welfare through bartering and other forms of economic aid between Latin American and Caribbean nations, and was initially promoted as an 'alternative' to the Free Trade Area of the Americas (FTAA) championed by the United States in the early 2000s.

ALBA was, in fact, an alternative to the free market proposal of the United States and its allies, but its founders decided to drop that reference and instead called it an 'alliance'. The Cuba-Venezuela model was broadened to eventually include nine more countries, with Venezuela usually playing the role of patron or financial backer, and Cuba providing the manpower and technical assistance.

It is important to highlight the role of Cuba, which since the early 1960s had been sending thousands of health workers to Africa, Asia and Latin America publicized as humanitarian efforts but with evident political undertones. Critics, who often termed these strategies 'doctor diplomacy', ${ }^{7}$ called them out as an attempt by Fidel Castro to spread the socialist ideology while eliciting sympathy for the Cuban revolution. Chavez launched a renewed version of these programs in Venezuela in the early 2000s, through a series of

${ }^{6}$ See Convenio Integral de Cooperación entre la República de Cuba y la República Bolivariana de Venezuela [Integral Cooperation Accord] (2017) link 5.

7 Beato-Nuñez, et al. (2000) link 6. 
programs called 'Missions' (Misiones), which became the centerpiece of that country's social policies and Chavez's main vote purchasing strategy and clientelistic political platform. ${ }^{8}$

ALBA was much more than a political agreement. Its trade component entailed the launching of a virtual regional currency,the SUCRE, that would be used for commercial exchanges among those participating in ALBA's trading bloc instead of the U.S. dollar. ${ }^{9}$ The SUCRE was poised to become a hard currency similarly to the European Union's Euro, but its implementation has met some obstacles that are beyond the scope of this article. ${ }^{10}$

Taking advantage of record high oil prices that lasted until the beginning of the present decade, Chavez directed billions of US dollars toward the promotion of social welfare programs around Latin America and the Caribbean. This strategy allowed Chavez to also spread his political ideology and build strong alliances in the region and beyond. ${ }^{11}$ ALBA also gave Cuba a much-needed lifeline to stay afloat and brought renewed visibility to the purported accomplishments of the Castro revolution regarding social programs and accessible healthcare.

As oil prices plummeted and Chavez succumbed to a terminal disease, ALBA lost Venezuela's financial backing and the political support of its main promoter. Preoccupied with the deep economic and political crisis that resulted in part from the sharp decline in revenues that hit Venezuela, President Nicolas Maduro, Chavez's designated successor, has been unable to maintain the position of influence that his country once had in the region, let alone garner political support for himself.

At the time of writing, the once incredibly wealthy Venezuela is immersed into the deepest economic crisis of its history. With more than $80 \%$ of the population living under the poverty line, widespread scarcity of foodstuff and medicines, one of the highest murder rates in the region, and an openly authoritarian regime -the South American country has gone from riches to rags in less than a decade and the regional efforts it supported have obviously suffered as a consequence.

The absence of Venezuela at the helm of ALBA and the recent shift in the regional political landscape has been a debilitating factor for the sub-regional agreement, at least in the short term. Only time will tell if these developments signify the dusk of this regional initiative, or if on the contrary, they only represent a hiccup in an otherwise successful journey toward the realization of Simon Bolivar's dream.

\section{The rise and transformation of UNASUR}

The rise of UNASUR, unlike the case of ALBA cannot be credited solely to Chavez's influence. South American nations had already worked toward establishing important subregional trading blocs like CARICOM, SICA, CAN and MERCOSUR, but these have fallen short of the idea of a full and efficient integration. Table 1 shows the most important regional agreements in the region during the $20^{\text {th }}$ century.

8 Gomez (2012).

9 See Sucrealba (2017) link 7.

10 Rosales et al. (2011) link 8.

11 Corales and Penfold-Becerra (2011). 
Table 1. Regional and sub-regional agreements in Latin American and the Caribbean

\begin{tabular}{|l|l|}
\hline Agreement & Date \\
\hline Central American Common Market (CACM) & 1960 \\
\hline Latin America Free Trade Association (LAFTA) & 1961 \\
\hline Caribbean Free Trade Area (CARIFTA) & 1969 \\
\hline Andean Common Market (ACM) & 1969 \\
\hline CARICOM & 1973 \\
\hline Latin American Integration Association (LAIA) & 1980 \\
\hline MERCOSUR & 1991 \\
\hline ALBA & 2004 \\
\hline UNASUR & 2008 \\
\hline
\end{tabular}

Chavez's political clout and economic power was certainly important for the creation of UNASUR in 2008, but the structure of this sub-regional agreement appears to be less dependent on Venezuela than ALBA. Even after the death of Chavez and the change of fate that continues to affect the once wealthy and influential South American nation, UNASUR members seem to be determined toward reaching their goal.

Very much like in the case of the European Union, economic integration has been only part of UNASUR's plan. Its goals extend to policies and action plans regarding political agreements, community identity, energy cooperation, environment, democracy, food, health and education. ${ }^{12}$ The group of twelve member nations (Table 2), some of which are also part of CAN, MERCOSUR, the Alliance of the Pacific (AP), and CARICOM agreed to create an ambitious supranational structure comprising four bodies, ${ }^{13}$ twelve ministerial councils, a parliament, a regional bank, and an Institute of Government in Health. The group has also admitted two observers, Mexico and Panama, and its current rotating pro tempore president is Argentina's Mauricio Macri.

Table 2. UNASUR membership

\begin{tabular}{|l|l|}
\hline Country & Regional and sub-regional membership \\
\hline Argentina & Andean Community (CAN)-Associate \\
& MERCOSUR \\
\hline Bolivia & Andean Community (CAN) \\
& MERCOSUR-Associated \\
\hline Brazil & Andean Community (CAN)-Associate \\
& MERCOSUR \\
\hline Chile & Andean Community (CAN)-Associate \\
& MERCOSUR-Associated \\
\hline Colombia & Andean Community (CAN) \\
& MERCOSUR-Protocol of accession \\
& CARICOM-Observer state \\
\hline
\end{tabular}

12 SELA Report at 9; See also, article 21 UNASUR Constitutive Treaty.

13 See, article 5 UNASUR Constitutive Treaty. 


\begin{tabular}{|l|l|}
\hline Country & Regional and sub-regional membership \\
\hline Ecuador & $\begin{array}{l}\text { Andean Community (CAN) } \\
\text { MERCOSUR-Protocol of accession }\end{array}$ \\
\hline Guyana & MERCOSUR-Framework agreement \\
& CARICOM \\
\hline Paraguay & Andean Community (CAN)-Associate \\
& MERCOSUR \\
\hline Peru & Andean Community (CAN) \\
& MERCOSUR-Protocol of accession \\
\hline Suriname & MERCOSUR-Framework agreement \\
& CARICOM \\
\hline Uruguay & Andean Community (CAN)-Associate \\
& MERCOSUR \\
\hline Venezuela & $\begin{array}{l}\text { MERCOSUR-Suspended } \\
\text { CARICOM-Observer state }\end{array}$ \\
\hline Mexico (observer state) & $\begin{array}{l}\text { MERCOSUR-Observer state } \\
\text { CARICOM-Observer state }\end{array}$ \\
\hline Panama (observer state) & \\
\hline Trinidad and Tobago (proposed state) & CARICOM \\
\hline
\end{tabular}

The legal framework of UNASUR rests on a Constitutive Treaty signed in 2008 but which entered into force on March 11, 2011. Given their membership to other trading blocs, UNASUR members have been particularly careful to avoid duplicative efforts and potential conflicts that could affect any existing agreements between them, and have vowed to harmonize UNASUR with other regional arrangements.

Another important concern of UNASUR members has been the reduction of asymmetries that exist among the countries in the region, as a way to attain an equitable integration. Several formal declarations issued with the occasion of UNASUR high-level meetings have stressed the willingness and commitment of its members to create mechanisms of inclusion that level the playing field across the region by eliminating both structural and policy asymmetries. ${ }^{14}$

\section{INTERNATIONAL DISPUTE RESOLUTION SOUTH AMERICAN WAY}

A particularly interesting initiative of UNASUR members has been the establishment of a regional Centre for the Settlement of Investment Disputes. Initially proposed by Ecuador's president Rafael Correa in 2010 as an alternative to the World Bank's International Centre for Settlement of Investment Disputes (ICSID) ${ }^{15}$; UNASUR's arbitration center aims to offer a more transparent, accessible and balanced dispute resolution framework for investment-related disputes that arise among member nations. ${ }^{16}$

The proliferation of numerous multi-million dollar claims filed by foreign investors against several South American countries during the last two decades contributed to

14 Permanent Secretariat of SELA (2017) link 9.

15 See, ICSID (2017) link 10.

16 See, Cancilleria (2017) link 11. 
exacerbate the criticism levied on the traditional dispute resolution framework set up under the aegis of the World Bank during the 1960s. Since the filing of the first investment arbitration claim in 1972, ICSID has become the premier international forum for the protection of foreign investors.

The Center had registered 650 cases, as of December 2017, of which a significant number involved Latin American states as respondents. ${ }^{17}$ The late 1990 s witnessed an upsurge in the number of cases, the majority of which were logged against Argentina and later on Venezuela, in connection with economic activities of foreign investors in those countries. ${ }^{18}$ Ecuador and Bolivia also became targets of ICSID arbitration claims but to a minor extent. ${ }^{19}$ As the docket of ICSID grew, so did the criticism toward the system.

A common reproach was the perception of bias in favor of industrialized western countries and the corporations based in their territories. Moreover, given the close connection and economic interdependence between ICSID and the World Bank, some expressed concern that their access to credit from the latter might be affected by their posture toward the former. ${ }^{20}$

Another apprehension about ICSID was the cost and complexity of the proceedings before it, which often times required states to retain prohibitively expensive legal counsel to match their corporate opponents. This structural issue, some argued, hindered access to justice and efficiency. ${ }^{21}$ Another criticism to ICSID was the absence of an effective appeal or review process that, unlike the existing annulment mechanism set forth in article 52 of ICSID Convention, ${ }^{22}$ could help foster more predictability and consistency.

Both Bolivia and Ecuador denounced the ICSID Convention in 2007 and 2009, respectively, ${ }^{23}$ and Venezuela followed suit in 2012. Even though many perceived these withdrawals as a tactical move by the governments of the denouncing countries to shield themselves from a series of imminent claims; at least in the case of Venezuela, foreign investors have continued to file claims under other (bilateral investment) treaty provisions therefore contributing to prolong the status quo. Ironically, the Venezuelan government has also trusted its legal defense to foreign - U.S. based - law firms. ${ }^{24}$

Almost seven years after it was initially proposed, UNASUR's Center for Settlement of Investment Disputes is yet to see the light of day. ${ }^{25}$ Despite many efforts to make the proposal a reality, the state members of UNASUR have not been able to reach consensus regarding its framework. Notwithstanding, in January 2016, a high level group of experts

17 ICSID, The ICSID Caseload-Statistics (2018) link 12.

18 At the time of writing, the current figures are 54 cases filed against Argentina and 44 cases filed against Venezuela.

19 The total of cases filed against Ecuador is 14, and 4 against Bolivia.

20 Grant (2015) 6.

21 Grant (2015) 13.

22 ICSID Convention, article 52.

23 The depositary received Bolivia's notice of denunciation of the ICSID Convention on May 7 , 2007, which pursuant to Article 71 of the Convention, took effect on November 3, 2007. The depositary received Ecuador's notice of denunciation of the ICSID Convention on July 6, 2009, which pursuant to Article 71 of the Convention, took effect on January 7, 2010.

${ }^{24}$ Argentina, on the other hand, pursued a different strategy by assembling a hybrid team of public officials and private practitioners who were able to provide a cost efficient legal representation and amass a great deal of experience in representing state entities.

25 Sarmiento (2016). 
that met in Montevideo, Uruguay to fine-tune the Rules and the Code of Conduct of Arbitrators ${ }^{26}$ reportedly reached consensus on about eighty percent of the proposal. ${ }^{27}$

The most current version of the Rules addresses several important matters including the exclusion of certain types of disputes (health, environment, education, energy) from being resolved by arbitration unless the states expressly agree to include them. ${ }^{28}$ Another important feature of UNASUR's Rules is the inclusion of a three-pronged approach to dispute resolution not just confined to arbitration (article 16 et seq.) but also including a facilitation mechanism (article 11) and conciliation (article 12). The Centre is also supposed to have a list of neutrals proposed by the member states, and subject to the Centre's Code of Conduct.

As an additional protection mechanism, the draft Rules also contain a provision allowing member states to require the exhaustion of local remedies as a precondition to the submission of the dispute to arbitration. On the other end of the spectrum, at the post-award stage, UNASUR's Rules incorporate an appeals mechanism geared to correct errors in the application or interpretation of the law, similar to the one that exists under the Understanding on Rules and Procedures Governing the Settlement of Disputes (DSU) and the Working Procedures for Appellate Review (Working Procedures) of the World Trade Organization. ${ }^{29}$

The proposed UNASUR Centre certainly addresses many of the concerns raised by Latin American countries about the ICSID mechanism. If and when the Centre comes to fruition its effectiveness will depend on how it is implemented, the level of cooperation of its member states, and the receptivity of its users. Predictably, the idea of a South American investment dispute resolution mechanism has met some criticism mainly related to the perceived risk of political manipulation of UNASUR by its members.

Similarly to how some South American nations have accused ICSID for being tilted to favor of powerful transnational interests; those on the other side of the isle have likewise criticized the establishment of a Centre motivated by disgruntled disputants. Regardless of the validity of this concern, UNASUR's member nations have the duty to foster the credibility and legitimacy of this new mechanism not only to their immediate stakeholders but also to the world.

\section{CONCLUSION}

The two most recent efforts of regional integration in Latin America represented by ALBA and UNASUR have moved beyond the traditional economic agreements toward and more comprehensive undertaking that pays attention to other social and political issues of common interest to the member states. At least in the case of ALBA, the excessive reliance on the financial and political support of Venezuela was both the driving force behind it and also the main obstacle for its development.

In the case of UNASUR, the situation appears to be slightly different, and the structure more stable. In this regard, UNASUR members have also developed initiatives that go beyond the traditional scheme of a regional integration regime. A noteworthy initiative is the launching of a Centre for the Settlement of Investment Disputes, which purports to offer an alternative to the current mechanism sponsored by the World Bank. UNASUR's Centre

26 Fach Gomez and Titi (2016).

27 Fach Gomez and Titi (2016).

28 Grant (2015) 28.

29 Perez-Salgado, Perez-Lozada (2016) link 13. 
has been subject to ample debate for more than seven years but it has not been launched yet. We will have to wait until that happens to assess whether the effort was worthwhile to the state members, its citizens and the foreign investors that engage in business with those states.

\section{LITERATURE}

Corrales, Javier, Penfold-Becerra, Michael, Dragon In The Tropics: Hugo Chávez And The Political Economy Of Revolution In Venezuela (Brookings Institution Press 2011).

Fach Gomez, Katia and Titi, Catharine, 'UNASUR Centre for Settlement of Investment Disputes: Comments on the Draft Constitutive Agreement' (2016) 3 Investment Treaty News $<$ https://www. iisd.org/itn/2016/08/10/unasur-centre-for-the-settlement-of-investment-disputes-comments-onthe-draft-constitutive-agreement-katia-fach-gomez-catharine-titi/> accessed 30 November 2017.

Gómez, Manuel, 'Malleable Law, The (Mis)Use of Legal Tools in the Pursuit of a Political Agenda' (2012) 3 ILSA Journal of International \& Comparative Law 509-54.

Kendall, Grant, 'The ICSID Under Siege: UNASUR and the Rise of a Hybrid Regime for International Investment Arbitration' (2015) 26 Osgoode Legal Studies Research Paper Series, paper 108 $<$ http://digitalcommons.osgoode.yorku.ca/olsrps/108/> accessed 20 December 2017.

Sarmiento, María Gabriela, 'The UNASUR Centre for Settlement of Investment Disputes and Venezuela: Will Both Ever See the Light at the End of the Tunnel?' (2016) 4 Journal of World Investment \& Trade 658-80.

\section{LINKS}

1. Baumann, R. Integration in Latin America-Trends and challenges, ECLAC, January 2008 (2017) $<$ www20.iadb.org/intal/catalogo/PE/2008/01306.pdf> accessed 12 December 2017.

2. Indart, G., Lengyel, M., Latin American Economic Integration: Sub-regional arrangements and patterns of trade, Focal/CIS Research papers, 1995 (2017) < https://idl-bnc-idrc.dspacedirect.org/ bitstream/handle/10625/29586/115753.pdf?sequence=1> accessed 10 December 2017.

3. Portalalba (2017) <http://www.portalalba.org/index.php/> accessed 11 November 2017.

4. UNASURSG (2017) <http://www.unasursg.org/en> accessed 13 November 2017.

5. Convenio Integral de Cooperación entre la República de Cuba y la República Bolivariana de Venezuela [Integral Cooperation Accord] (2017) <http://ctp.iccas.miami.edu/FOCUS_Web/ Issue 54.htm> accessed 10 December 2017.

6. Beato-Nuñez, V., et al. Castro's Doctor Diplomacy, 5(5) Medical Sentinel 163-66, 2000 (2017) $<$ www.jpands.org/hacienda/article47.html> accessed 22 November 2017.

7. Sucrealba (2017) <www.sucrealba.org> accessed 29 November 2017.

8. Rosales, A. et al. Sucre: A monetary tool toward economic complementarity, Research on Money and Finance, Discussion paper No. 31, Department of Economics, SOAS, 2011 (2017) <www. researchgate.net/profile/Antulio_Rosales/publication/254449183_Sucre_A_Monetary_Tool_ Toward_Economic_Complementarity/links/55b239f408ae9289a0852243/Sucre-A-MonetaryTool-Toward-Economic-Complementarity.pdf $>$ accessed 22 November 2017.

9. Permanent Secretariat of SELA, Union of South American Nations (UNASUR) 45, August, 2015 (2017) <www.sela.org/media/1950656/di-10-15-unasur.pdf $>$ accessed 18 November 2017.

10. ICSID (2017) <https://icsid.worldbank.org> accessed 10 December 2017.

11. Cancilleria (2017) <www.cancilleria.gob.ec/unasur-advances-in-the-creation-of-a-dispute-resolu tion-centre/> accessed 10 December 2017.

12. ICSID, The ICSID Caseload-Statistics, Issue 2018-1. (2018) <https://icsid.worldbank.org/en/ Documents/resources/ICSID\%20Web\%20Stats\%202018-1(English).pdf $>$ accessed 10 December 2017.

13. Perez-Salgado, D., Perez-Lozada, F. New investment arbitration center in Latin America: UNASUR, A hybrid example of success or failure? Kluwer Arbitration Blog, May 27, 2016 (2017) <http://arbitrationblog.kluwerarbitration.com/2016/05/27/unasur/?print=pdf $>$ accessed 8 December 2017. 